\title{
Audit Sistem Informasi Akademik Pada Universitas XYZ Menggunakan COBIT 5 Pada Domain MEA
}

\author{
Halim Agung'), Johanes Fernandes Andry ${ }^{2)}$ \\ Teknik Informatika, Fakultas Teknologi dan Desain \\ Jalan Lodan Raya No. 2 Ancol, Jakarta Utara 14430 \\ ${ }^{1)}$ Email: hagung@bundamulia.ac.id \\ 2)Email: jandry@bundamulia.ac.id
}

\begin{abstract}
Abstrak: The study was conducted to measure the level of capability of the academic information system towards the achievement of the university's vision and mission. The researcher examined the impact that occurred on the university regarding the level of capability of the academic information system. The focus of this study is about effectiveness, efficiency, functional information technology units in academic information systems, integrity, saveguarding assets, reliability, confidentiality, availability and security. The researcher conducts literature studies, interviews, distributing questionnaires, examines documents and analyzes the results of questionnaire dissemination and document checking to obtain actual values from the level of capability of academic information systems and factors that affect academic information systems. The researcher processes the statistical data in the form of validity and reliability tests. Researchers use the COBIT 5 framework on 1 domain, namely the Monitor, Evaluate and Assess (MEA) domain to conduct research on the capabilities of academic information systems. The results of the study are in the form of recommendations for solutions for improving the capabilities of academic information systems at universities.
\end{abstract}

Kata kunci: audit, COBIT 5, MEA, information systems academic

\begin{abstract}
Penelitian dilakukan untuk mengukur tingkat kapabilitas sistem informasi akademik terhadap ketercapaian visi dan misi universitas. Peneliti meneliti dampak yang terjadi pada universitas terkait tingkat kapabilitas sistem informasi akademik. Fokus penelitian ini adalah tentang keefektifan, keefisienan, unit fungsional teknologi informasi pada sistem informasi akademik, integritas, saveguarding assets, reliability, confidentiality, availabilty dan security. Peneliti melakukan studi pustaka, wawancara, penyebaran kuisioner, pemeriksaan dokumen dan melakukan analisis terhadap hasil penyebaran kuisioner dan pemeriksaan dokumen untuk mendapatkan nilai aktual dari tingkat kapabilitas sistem informasi akademik dan faktor yang mempengaruhi sistem informasi akademik. Peneliti melakukan pengolahan data statistik berupa uji validitas dan uji reliabilitas. Peneliti menggunakan framework COBIT 5 pada 1 domain yaitu domain Monitor, Evaluate and Assess (MEA) untuk melakukan penelitian tentang kapabilitas sistem informasi akademik. Hasil dari penelitian berupa rekomendasi solusi untuk peningkatan kapabilitas sistem informasi akademik pada universitas.
\end{abstract}

Keywords: audit, COBIT 5, MEA, sistem informasi akademik

\section{PENDAHULUAN}

Universitas XYZ yang terletak di Jakarta Utara telah menggunakan Sistem Informasi Akademik (SIA) merupakan salah satu bentuk pemanfaatan teknologi informasi berupa layanan software dalam dunia pendidikan termasuk di dalamnya proses informasi akademik mahasiswa, dosen serta layanan akademik. SIA dapat secara efektif digunakan sebagai sarana pendukung proses beljar mengajar yang didukung oleh sumber daya teknologi informasi yang baik oleh organisasi terkait [1]. Evaluasi kinerja maupun operasional dari SIA dan orang yang terlibat didalamnya, perlu dilakukan audit, salah satu alat untuk mengevaluasi kinerja sistem maupun lingkunganya adalah menggunakan standart COBIT 5. Dengan adanya audit sistem informasi diharapkan dapat memberikan rekomendasi dalam membantu meningkatkan kualitas layanan teknologi informasi maupun operasional SIA sehingga dapat mendukung tercapainya visi dan misi dari Universitas XYZ.

\section{METODE PENELITIAN}

Metodologi penelitian yang dilakukan dan tahapan-tahapan penulis dalam mengambil ataupun 
memperoleh data dari sumber, mulai dari survei awal, wawancara dan kuisioner ditujukan pada Gambar 1. Diagram Alir Penelitian.

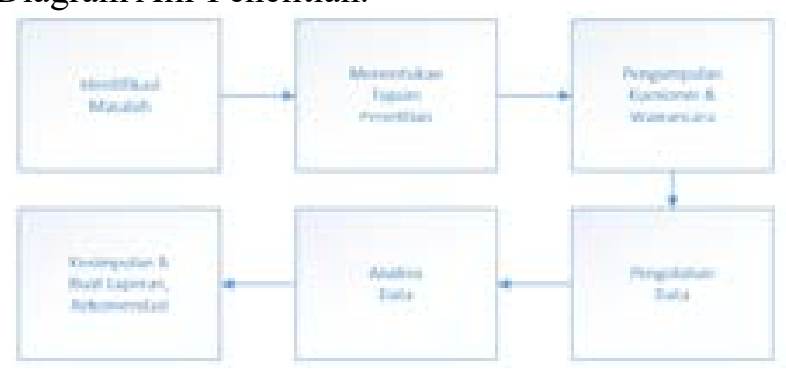

Gambar 1. Diagram Alir Penelitian [1-3]

Identifikasi masalah merupakan tahapan awal dalam prosedur penelitian yang kami lakukan. Karena pada tahap ini kami dapat menentukan ruang lingkup (scope), beserta dengan tujuan dari penelitian ini. Pemeriksaan Lapangan dilakukan, pada tahap ini penulis mendapatkan informasi dengan cara mengumpulkan data dengan pihak-pihak yang terkait yang menggunakan beberapa metode yang dapat dilakukan seperti; wawancara, kuesioner, dan melakukan survey langsung ke tempat penelitian dilakukan. Pelaporan dilakukan setelah proses pengumpulan data, maka akan didapat data yang akan diproses untuk dihitung berdasarkan perhitungan kapabiliti level. Pada tahap ini yang akan dilakukan penulis adalah memberikan informasi berupa hasilhasil dari audit menggunakan COBIT 5. COBIT adalah sebuah kerangka kerja yang mengkombinasikan pemikiran modern dalam pengelolaan perusahaan dan teknik manajemen, serta pemodelan untuk Tabel 1 COBIT 5 Process Capability Model [6-9]

\begin{tabular}{|c|c|}
\hline Iavi! & Descripnant \\
\hline $\begin{array}{l}\text { Lovel O. Incompiest } \\
\text { proces:. }\end{array}$ & Proses bak dapd mebtapa bujuminya \\
\hline $\begin{array}{l}\text { Level 1: Poformed } \\
\text { prosest. }\end{array}$ & $\begin{array}{l}\text { Prosesnya sudah ada dan mencapai } \\
\text { bayannya sendirn. Pada lenel "Prociss } \\
\text { Performavee" }\end{array}$ \\
\hline $\begin{array}{l}\text { Lavel 2: Kaneged } \\
\text { provest. }\end{array}$ & 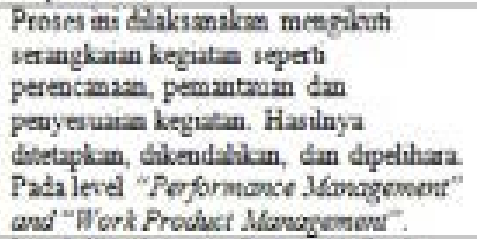 \\
\hline $\begin{array}{l}\text { Lnel 3; Establebed } \\
\text { Erocers. }\end{array}$ & 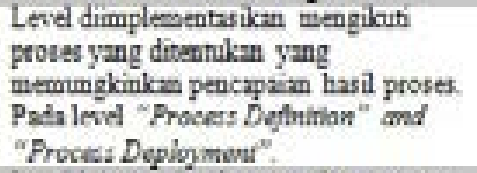 \\
\hline $\begin{array}{l}\text { Lnel } 4 \text {; Predictable } \\
\text { precers }\end{array}$ & 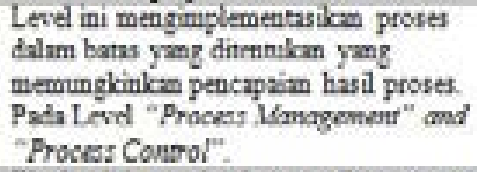 \\
\hline $\begin{array}{l}\text { Lnel 5: Optouzbs } \\
\text { procers }\end{array}$ & 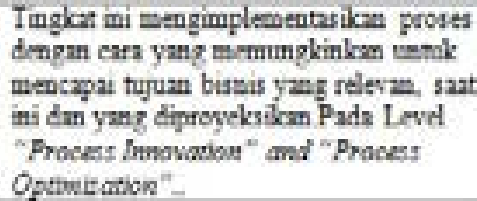 \\
\hline
\end{tabular}

meningkatkan nilai dan kepercayaan terhadap sebuah sistem informasi [4]. COBIT 5 terdiri dari lima domain EDM (Evaluate, Direct and Monitor); APO (Align, Plan and Organise); BAI (Build, Acquire and Implement); DSS (Deliver, Service and Support) dan MEA; (Monitor, Evaluate and Assess) dengan total proses sebanyak 37 proses [5]. Pada penelitian ini hanya focus pada domain MEA. Perhitungan kapabiliti level dilakukan mengacu pada hasil wawancara, survey dan rekapitulasi hasil penyebaran kuesioner. Berdasarkan hasil kapabilitas level yang mencerminkan kinerja saat ini. Tabel 1. COBIT 5 Process Capability Model, Level kapabilitas proses yang digunakan di dalam penilaian yang terdiri dari enam level.

\section{HASIL DAN PEMBAHASAN}

Pada bagian ini peneliti akan membahas proses yang akan dibahas adalah pada domain MEA, akan dibahas mengenai hasil analisis level kapabilitas pada SIA universitas XYZ.

MEA01 Monitor, evaluate and assess performance and conformance. Deskripsi prosesnya adalah mengumpulkan, memvalidasi dan mengevaluasi tujuan bisnis, TI dan proses serta metrik. Pantau proses yang dilakukan terhadap kinerja yang telah disepakati dan tujuan dan metrik kesesuaian dan memberikan pelaporan yang sistematis dan tepat waktu. Tujuan prosesnya adalah memberikan transparansi kinerja dan kesesuaian dan mendorong tercapainya tujuan. Harapan yang ingin dicapai pada proses ini adalah di level 4, predictable process. Berikut adalah sub-sub domain dari MEA01 Monitor, evaluate and assess performance and conformance:

Management Practice MEA01.01 Establish a monitoring approach. Deskripsi prosesnya adalah pemangku kepentingan untuk membangun dan memelihara pendekatan pemantauan untuk menentukan tujuan, cakupan dan metode untuk mengukur solusi dan layanan bisnis pengiriman dan kontribusi terhadap tujuan perusahaan. Integrasikan pendekatan ini dengan kinerja perusahaan sistem manajemen.

Kegiatan dari MEA01.01 Establish a monitoring approach, adalah: 1) Identifikasi pemangku kepentingan (misalnya, manajemen, pemilik proses dan pengguna); 2) Terlibatlah dengan pemangku kepentingan dan komunikasikan persyaratan dan tujuan perusahaan untuk memantau, menggabungkan dan melaporkan, menggunakan metode umum definisi (mis., glosarium perusahaan, metadata dan 
taksonomi), baselining dan tolok ukur; 3) Sejajarkan dan terus menjaga pendekatan monitoring dan evaluasi dengan pendekatan perusahaan dan alat yang akan digunakan untuk pengumpulan data dan pelaporan perusahaan (mis., aplikasi intelijen bisnis); 4. Setuju pada sasaran dan metrik (mis., Kesesuaian, kinerja, nilai, risiko), taksonomi (klasifikasi dan hubungan antara sasaran dan metrik) dan data (bukti) retensi; 5) Setuju dalam proses manajemen siklus hidup dan perubahan kontrol untuk pemantauan dan pelaporan. Sertakan peluang perbaikan untuk pelaporan, metrik, pendekatan, baselining dan benchmarking; 6) Meminta, memprioritaskan dan mengalokasikan sumber daya untuk pemantauan (mempertimbangkan kesesuaian, efisiensi, efektivitas dan kerahasiaan); dan 7) Secara berkala memvalidasi pendekatan yang digunakan dan mengidentifikasi pemangku kepentingan, persyaratan dan sumber daya yang baru atau berubah.

Hasil analisis dari kegiatan dari MEA01.01 Establish a monitoring approach adalah institusi sudah melakukan seluruh proses diatas dan disimpulkan bahwa untuk proses MEA01.01 yaitu Establish a monitoring approach, di level 2, managed process, yang pencapaiannya berada pada sub level performance management attribute.

Management Practice MEA01.02 Set performance and conformance targets. Deskripsi prosesnya adalah bekerja dengan para pemangku kepentingan untuk menentukan, meninjau secara berkala, memperbarui dan menyetujui kinerja dan kesesuaian target dalam sistem pengukuran kinerja.

Kegiatan dari MEA01.02 Set performance and conformance targets adalah: 1) Tentukan dan tinjau secara berkala dengan pemangku kepentingan mengenai sasaran dan metrik untuk mengidentifikasi item hilang yang signifikan dan menentukan kewajaran target dan toleransi; 2) Mengkomunikasikan perubahan yang diusulkan terhadap kinerja dan target kesesuaian dan toleransi (berkaitan dengan metrik) dengan pemangku kepentingan uji tuntas utama (misalnya, hukum, audit, SDM, etika, kepatuhan, keuangan); 3) Publikasikan target dan toleransi yang berubah kepada pengguna informasi ini; dan 4) Evaluasi apakah sasaran dan metrik memadai, yaitu spesifik, terukur, dapat dicapai, relevan dan terikat waktu (SMART).

Hasil analisis dari kegiatan dari MEA01.02 Set performance and conformance targets adalah Institusi sudah melakukan seluruh proses diatas dan disimpulkan bahwa untuk proses MEA01.02 yaitu Set performance and conformance targets, di level 2, managed process, yang pencapaiannya berada pada sub level performance management attribute.

Management Practice MEA01.03 Collect and process performance and conformance data. Deskripsi prosesnya adalah mengumpulkan dan mengolah data yang tepat waktu dan akurat dengan pendekatan perusahaan.

Kegiatan dari MEA01.03 Collect and process performance and conformance data, adalah: 1) Kumpulkan data dari proses yang didefinisikanotomatis, jika memungkinkan; 2) Menilai efisiensi (usaha yang berkaitan dengan wawasan yang diberikan) dan kesesuaian (kegunaan dan makna) dan memvalidasi integritas (akurasi dan kelengkapan) data yang terkumpul; 3) Data agregat untuk mendukung pengukuran metrik yang disepakati; 4) Sejajarkan data gabungan dengan pendekatan dan tujuan pelaporan perusahaan; dan 5) Gunakan alat dan sistem yang sesuai untuk pengolahan dan format data untuk analisis.

Hasil analisis dari kegiatan dari MEA01.03 Collect and process performance and conformance data, adalah Institusi sudah melakukan seluruh proses diatas dan disimpulkan bahwa untuk proses MEA01.03 yaitu Collect and process performance and conformance data, di level 2, managed process, yang pencapaiannya berada pada sub level performance management attribute.

Management Practice MEA01.04 Analyse and report performance. Deskripsi prosesnya adalah tinjau dan laporkan kinerja secara berkala target, menggunakan metode yang ringkas semua pandangan tentang kinerja TI dan sesuai dengan sistem pemantauan perusahaan.

Kegiatan dari MEA01.04 Analyse and report performance, adalah: 1) Merancang laporan kinerja proses yang ringkas, mudah dimengerti, dan disesuaikan dengan berbagai kebutuhan manajemen dan khalayak. Memudahkan pengambilan keputusan yang efektif dan tepat waktu (mis., scorecard, laporan lampu lalu lintas) dan memastikan bahwa penyebab dan pengaruh antara sasaran dan metrik adalah dikomunikasikan dengan cara yang mudah dimengerti; 2) Bandingkan nilai kinerja dengan target dan tolok ukur internal dan, jika mungkin, untuk tolok ukur eksternal (pesaing industri dan kunci); 3) Merekomendasikan perubahan pada sasaran dan metrik, jika sesuai; 4) Bagikan laporan kepada pemangku kepentingan terkait; 5) Menganalisis penyebab penyimpangan terhadap target, memulai tindakan perbaikan, menetapkan tanggung jawab untuk remediasi, dan tindak lanjut. Pada waktu yang 
tepat, tinjau semua penyimpangan dan cari akar penyebab, bila perlu. Dokumentasikan masalah untuk panduan lebih lanjut jika masalah berulang; dan 6) Bila memungkinkan, kaitkan antara pencapaian target kinerja dengan pencapaian sistem kompensasi penghargaan organisasi.

Hasil analisis dari kegiatan dari MEA01.04 Analyse andreportperformance, adalah Institusi sudah melakukan seluruh proses diatas dan disimpulkan bahwa untuk proses MEA01.04 yaitu Analyse and report performance, di level 3, established process, yang pencapaiannya berada pada sub level process definition attribute.

Management Practice MEA01.05 Ensure the implementation of corrective actions. Deskripsi prosesnya adalah membantu pemangku kepentingan dalam mengidentifikasi, memulai dan melacak tindakan korektif untuk mengatasi anomali.

Kegiatan dari MEA01.05 Ensure the implementation of corrective actions, adalah: 1) Review management responses, options and recommendations to address issues and major deviations; 2) Ensure that the assignment of responsibility for corrective action is maintained; 3 ) Track the results of actions committed; dan 4) Report the results to the stakeholders.

Tabel 2 Process Capability Domain MEA01 Monitor, evaluate and assess performance and conformance

\begin{tabular}{|c|c|c|c|}
\hline No, & Sub Dowan & Curvet & Expocted \\
\hline MEA 01.01 & $\begin{array}{l}\text { Etsabith a } \\
\text { monitoring approach }\end{array}$ & 2 & 4 \\
\hline MEAA01.02 & $\begin{array}{l}\text { Set performasee and } \\
\text { conformance target }\end{array}$ & 2 & 4 \\
\hline MEA01.03 & 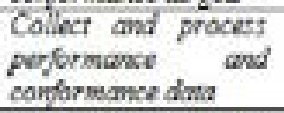 & 3 & 4 \\
\hline MEA01 04 & $\begin{array}{l}\text { Anajse and report } \\
\text { performamee }\end{array}$ & 2 & 4 \\
\hline MEA 01.05 & $\begin{array}{l}\text { Eerive the } \\
\text { beplementartion of } \\
\text { correcthe astions }\end{array}$ & 2 & 4 \\
\hline
\end{tabular}

Hasil analisis dari kegiatan dari MEA01.05 Ensure the implementation of corrective actions, adalah Institusi sudah melakukan seluruh proses diatas dan disimpulkan bahwa untuk proses MEA01.05 yaitu Ensure the implementation of corrective actions, di level 2, managed process, yang pencapaiannya berada pada sub level performance management attribute. Tabel 2 Process Capability Domain MEA01 Monitor, evaluate and assess performance and conformance, memperlihatkan keseluruhan summary dari domain MEA01.

MEA02 Monitor, evaluate and assess the system of internal control. Deskripsi prosesnya adalah terus memantau dan mengevaluasi lingkungan pengendalian, termasuk penilaian diri dan tinjauan kepastian independen. Aktifkan Manajemen mengidentifikasi kekurangan kontrol dan inefisiensi dan untuk memulai tindakan perbaikan. Merencanakan, mengatur dan memelihara standar penilaian pengendalian internal dan kegiatan penjaminan. Tujuan Prosesnya adalah mendapatkan transparansi bagi pemangku kepentingan utama mengenai kecukupan sistem pengendalian internal dan dengan demikian memberikan kepercayaan dalam operasi, kepercayaan terhadap pencapaian tujuan perusahaan dan pemahaman yang memadai terhadap risiko residual. Harapan yang ingin dicapai pada proses ini adalah di level 4, predictable process. Berikut adalah sub-sub domain dari MEA02 Monitor, evaluate and assess the system of internal control:

Management Practice MEA02.01 Monitor internal controls. Deskripsi prosesnya adalah terus memantau, patokan dan memperbaiki Lingkungan pengendalian dan pengendalian lingkungan untuk bertemu tujuan organisasi. Kegiatan dari MEA02.01 Monitor internal controls, adalah: 1) Melakukan kegiatan pengawasan dan evaluasi pengendalian internal berdasarkan standar tata kelola organisasi dan kerangka kerja yang diterima industri dan praktek. Sertakan pemantauan dan evaluasi efisiensi dan efektivitas tinjauan pengawas manajerial; 2) Pertimbangkan evaluasi independen terhadap sistem pengendalian internal (mis., Oleh audit internal atau rekan kerja); 3) Identifikasi batasbatas sistem pengendalian internal TI (misalnya, pertimbangkan bagaimana pengendalian internal TI organisasi memperhitungkan outsourcing dan / atau pengembangan lepas pantai atau kegiatan produksi); 4) Pastikan bahwa kegiatan pengendalian telah dilakukan dan pengecualian segera dilaporkan, ditindaklanjuti dan dianalisis, dan tindakan perbaikan yang tepat adalah diprioritaskan dan diimplementasikan sesuai profil manajemen risiko (misalnya, mengklasifikasikan pengecualian tertentu sebagai risiko utama dan risiko lainnya sebagai risiko non-kunci); 5) Menjaga sistem pengendalian internal TI, mengingat perubahan yang sedang berlangsung dalam bisnis dan risiko TI, lingkungan pengendalian organisasi, bisnis yang relevan dan proses TI, dan risiko TI. Jika ada kesenjangan, evaluasi dan rekomendasikan perubahan; 6) Secara teratur mengevaluasi kinerja kerangka kontrol TI, benchmark terhadap standar industri yang berlaku dan praktik yang baik. Mempertimbangkan adopsi formal pendekatan perbaikan terus menerus terhadap 
pemantauan pengendalian internal; dan 7) Menilai status pengendalian internal penyedia layanan eksternal dan memastikan bahwa penyedia layanan mematuhi persyaratan hukum dan peraturan dan kewajiban kontraktual.

Hasil analisis dari Kegiatan dari MEA02.01 Monitor internal controls, adalah Institusi sudah melakukan seluruh proses diatas dan disimpulkan bahwa untuk proses MEA02.01 yaitu Monitor internal controls, di level 2, managed process, yang pencapaiannya berada pada sub level performance management attribute.

Management Practice MEA02.02 Review business process controls effectiveness. Deskripsi prosesnya adalah meninjau pengoperasian kontrol, termasuk peninjauan ulang memantau dan menguji bukti, untuk memastikan bahwa control dalam proses bisnis berjalan efektif. Sertakan kegiatan untuk menjaga bukti operasi yang efektif kontrol melalui mekanisme seperti periodik pengujian kontrol, pemantauan kontrol terus menerus, penilaian independen, perintah dan control pusat, dan pusat operasi jaringan. Ini menyediakan bisnis dengan kepastian efektivitas pengendalian untuk memenuhi persyaratan yang terkait dengan bisnis, peraturan dan tanggung jawab sosial. Kegiatan dari MEA02.02 Review business process controls effectiveness, adalah: 1) Memahami dan memprioritaskan risiko terhadap tujuan organisasi; 2) Identifikasi kontrol kunci dan kembangkan strategi yang sesuai untuk memvalidasi kontrol; 3) Identifikasi informasi yang secara persuasif akan menunjukkan apakah lingkungan pengendalian internal beroperasi secara efektif; 4) Mengembangkan dan menerapkan prosedur biaya-efektif untuk menentukan bahwa informasi persuasif didasarkan pada kriteria informasi; dan 5 . Pertahankan bukti efektivitas pengendalian.

Hasil analisis dari Kegiatan dari MEA02.02 Review business process controls effectiveness, adalah Institusi sudah melakukan seluruh proses diatas dan disimpulkan bahwa untuk proses MEA02.02 yaitu Review business process controls effectiveness, di level 2, managed process, yang pencapaiannya berada pada sub level performance management attribute.

Management Practice MEA02.03 Perform control self-assessments. Deskripsi prosesnya adalah mendororong manajemen dan pemilik proses untuk mengambil kepemilikan positif atas peningkatan pengendalian melalui a melanjutkan program self assessment untuk dievaluasi kelengkapan dan efektivitas Manajemen kontrol atas proses, kebijakan dan kontrak. Kegiatan dari MEA02.03 Perform control self-assessments, adalah: 1) Menjaga rencana dan ruang lingkup dan mengidentifikasi kriteria evaluasi untuk melakukan penilaian sendiri. Rencanakan komunikasi hasil self-assessment proses bisnis, TI dan manajemen umum dan dewan direksi. Pertimbangkan standar audit internal dalam merancang penilaian diri; 2) Tentukan frekuensi penilaian diri periodik, dengan mempertimbangkan keseluruhan efektifitas dan efisiensi pemantauan yang sedang berlangsung; 3) Tetapkan tanggung jawab untuk penilaian diri kepada individu yang tepat untuk memastikan objektivitas dan kompetensi; 4) Memberikan tinjauan independen untuk memastikan objektivitas penilaian-diri dan memungkinkan pembagian praktik pengendalian internal dari perusahaan lain; 5) Bandingkan hasil penilaian diri terhadap standar industri dan praktik yang baik; 6) Ringkaskan dan laporkan hasil penilaian diri dan tolok ukur untuk tindakan perbaikan; dan 7) Tentukan pendekatan yang disepakati dan konsisten untuk melakukan penilaian diri kontrol dan koordinasi dengan auditor internal dan eksternal. Hasil analisis dari Kegiatan dari MEA02.03 Perform control self-assessments, adalah Institusi sudah melakukan seluruh proses diatas dan disimpulkan bahwa untuk proses MEA02.03 yaitu Perform control self-assessments, di level 2, managed process, yang pencapaiannya berada pada sub level performance management attribute

Management Practice MEA02.04 Identify and report control deficiencies. Deskripsi prosesnya adalah Identifikasi kekurangan kontrol dan analisis dan identifikasi akar penyebab utamanya. Mengangkat control kekurangan dan melaporkan kepada pemangku kepentingan. Kegiatan dari MEA02.04 Identify and report control deficiencies, adalah: 1) Identifikasi, laporkan dan log kontrol pengecualian, dan tetapkan tanggung jawab untuk menyelesaikannya dan laporkan statusnya; 2) Pertimbangkan risiko perusahaan terkait untuk menetapkan ambang batas untuk eskalasi pengecualian dan kerusakan pengendalian; 3) Mengkomunikasikan prosedur untuk eskalasi pengecualian pengendalian, analisis akar penyebab, dan pelaporan kepada pemilik proses dan pemangku kepentingan TI; 4) Tentukan pengecualian kontrol mana yang harus dikomunikasikan kepada individu yang bertanggung jawab atas fungsi tersebut dan pengecualian mana yang harus ditingkatkan. Menginformasikan pemilik dan pemangku kepentingan yang terkena dampak; 5) Tindak lanjuti semua pengecualian untuk memastikan bahwa tindakan yang disepakati telah ditangani; dan 6) Mengidentifikasi, memulai, melacak dan 
menerapkan tindakan perbaikan yang timbul dari penilaian dan pelaporan pengendalian.

Hasil analisis dari Kegiatan dari MEA02.04 Identify and report control deficiencies, adalah Institusi sudah melakukan seluruh proses diatas dan disimpulkan bahwa untuk proses MEA02.04 yaitu Identify and report control deficiencies, di level 3, established process, yang pencapaiannya berada pada sub level process definition attribute.

Management Practice MEA02.05 Ensure that assurance providers are independent and qualified. Kegiatan dari MEA02.05 Ensure that assurance providers are independent and qualified, adalah: 1) Tetapkan kepatuhan terhadap kode etik dan standar yang berlaku (misalnya Kode Etik Profesi ISACA) dan (spesifik industri dan geografi) standar jaminan, misalnya, Standar Audit dan Jaminan TI ISACA dan Dewan Standar Audit dan Jaminan Internasional (IAASB) Kerangka Kerja Internasional untuk Keterlibatan Assurance (Kerangka Jaminan); 2) Menetapkan independensi penyedia penjamin; dan 3) Menetapkan kompetensi dan kualifikasi penyedia penjamin.

Hasil analisis dari Kegiatan dari MEA02.05 Ensure that assurance providers are independent and qualified, adalah Institusi sudah melakukan seluruh proses diatas dan disimpulkan bahwa untuk proses MEA02.05 yaitu Ensure that assurance providers are independent and qualified, di level 2, managed process, yang pencapaiannya berada pada sub level performance management attribute.

Management Practice MEA02.06 Plan assurance initiatives. Deskripsi prosesnya adalah merencanakan inisiatif penjaminan berdasarkan tujuan perusahaan dan prioritas strategis, risiko inheren, sumber daya kendala, dan pengetahuan perusahaan yang memadai.

Kegiatan dari MEA02.06 Plan assurance initiatives, adalah: 1) Tentukan pengguna yang diharapkan dari keluaran inisiatif jaminan dan objek peninjauan; 2) Lakukan penilaian risiko tingkat tinggi dan / atau penilaian kemampuan proses untuk mendiagnosis risiko dan mengidentifikasi proses TI yang penting; dan 3) Pilih, sesuaikan dan mencapai kesepakatan mengenai tujuan pengendalian untuk proses kritis yang akan menjadi dasar penilaian pengendalian.

Hasil analisis dari Kegiatan dari MEA02.06 Plan assurance initiatives, adalah Institusi sudah melakukan seluruh proses diatas dan disimpulkan bahwa untuk proses MEA02.06 yaitu Plan assurance initiatives, di level 3, established process, yang pencapaiannya berada pada sub level process definition attribute.

Management Practice MEA02.07 Scope assurance initiatives. Deskripsi prosesnya adalah Tentukan dan setujui dengan manajemen mengenai ruang lingkup prakarsa jaminan, berdasarkan pada tujuan penjaminan. Kegiatan dari MEA02.07 Scope assurance initiatives, adalah: 1) Tentukan cakupan aktual dengan mengidentifikasi tujuan perusahaan dan TI untuk lingkungan yang ditinjau, rangkaian proses dan sumber daya TI, dan semua entitas auditable yang relevan dalam perusahaan dan pihak luar perusahaan (misalnya, penyedia layanan), jika ada; 2) Tentukan rencana keterlibatan dan persyaratan sumber daya; 3) Tentukan praktik untuk mengumpulkan dan mengevaluasi informasi dari proses yang sedang dikaji untuk mengidentifikasi kontrol yang akan divalidasi, dan temuan saat ini (baik jaminan positif maupun kekurangan) untuk evaluasi risiko; 4) Tentukan praktik untuk memvalidasi rancangan dan hasil kontrol dan tentukan apakah tingkat efektivitas mendukung risiko yang dapat diterima (dipersyaratkan oleh penilaian risiko organisasi atau proses); dan 5) Bila efektivitas pengendalian tidak dapat diterima, tentukan praktik untuk mengidentifikasi risiko residual (dalam persiapan pelaporan).

Hasil analisis dari Kegiatan dari MEA02.07 Scope assurance initiatives, adalah Institusi sudah melakukan seluruh proses diatas dan disimpulkan bahwa untuk proses MEA02.07 yaitu Scope assurance initiatives, di level 2, managed process, yang pencapaiannya berada pada sub level performance management attribute.

Management Practice MEA02.08 Execute assurance initiatives. Deskripsi prosesnya adalah menjalankan inisiatif penjaminan yang direncanakan. Melaporkan pada temuan yang teridentifikasi. Berikan jaminan yang positif pendapat, bila sesuai, dan rekomendasi untuk perbaikan yang berkaitan dengan operasional yang teridentifikasi kinerja, kepatuhan eksternal dan pengendalian internal sistem residual risk. Kegiatan dari MEA02.08 Execute assurance initiatives, adalah: 1) Mempertajam pemahaman subjek IT assurance; 2) Perbaiki cakupan tujuan pengendalian kunci untuk subjek jaminan TI; 3) Uji keefektifan desain kontrol dari tujuan pengendalian kunci; 4) Sebagai alternatif / tambahan uji hasil tujuan pengendalian kunci; 5) Dokumentasikan dampak kelemahan pengendalian; 6) Berkomunikasi dengan manajemen selama pelaksanaan inisiatif sehingga ada pemahaman yang jelas tentang pekerjaan yang dilakukan dan kesepakatan dan penerimaan temuan 
awal dan rekomendasi; 7) Mengawasi kegiatan penjaminan dan memastikan pekerjaan selesai, memenuhi tujuan dan memiliki kualitas yang dapat diterima; dan 8) Memberikan manajemen laporan (selaras dengan kerangka acuan, cakupan dan standar pelaporan yang disepakati) yang mendukung hasil penelitian inisiatif dan memungkinkan fokus yang jelas pada isu-isu kunci dan tindakan penting.

Hasil analisis dari Kegiatan dari MEA02.08 Execute assurance initiatives, adalah Institusi sudah melakukan seluruh proses diatas dan disimpulkan bahwa untuk proses MEA02.08 yaitu Execute assurance initiatives, di level 2, managed process, yang pencapaiannya berada pada sub level performance management attribute. Tabel 3 Tabel Process Capability Domain MEA02 Monitor, evaluate and assess the system of internal control, memperlihatkan keseluruhan summary dari domain MEA02.

Tabel 3 Process Capability Domain MEA02 Monitor, evaluate and assess the system of internal control

\begin{tabular}{|c|c|c|c|}
\hline $\mathrm{Na}$ & Sab Domain & Carrent & Expected \\
\hline MEADL.01 & $\begin{array}{l}\text { Kowater basernat } \\
\text { cantrols }\end{array}$ & 2 & 4 \\
\hline MEA02.02 & 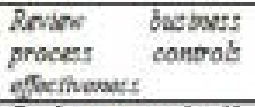 & 2 & 4 \\
\hline MEA02.03 & 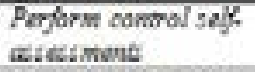 & 2 & 4 \\
\hline MEA02.04 & $\begin{array}{l}\text { folenny and repart } \\
\text { control difokiencids }\end{array}$ & 3 & 4 \\
\hline MEA0205 & 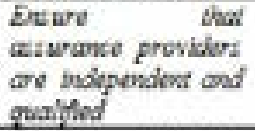 & 2 & 4 \\
\hline MEA02.06 & $\begin{array}{l}\text { Plav artarence } \\
\text { hithather }\end{array}$ & 3 & 4 \\
\hline MEA02.07 & $\begin{array}{l}\text { Scope atsarance } \\
\text { buifluthes }\end{array}$ & 2 & 4 \\
\hline MEA02.03 & $\begin{array}{l}\text { Exctuly atwance } \\
\text { bithathes }\end{array}$ & 2 & 4 \\
\hline
\end{tabular}

MEA03 Monitor, evaluate and assess compliance with external requirements. Deskripsi proses nya adalah evaluasi bahwa proses TI dan proses bisnis yang didukung TI sesuai dengan undang-undang, peraturan dan persyaratan kontrak. Mendapatkan jaminan bahwa persyaratan telah diidentifikasi dan dipatuhi, dan mengintegrasikan kepatuhan TI dengan kepatuhan perusahaan secara keseluruhan. Tujuan Prosesnya adalah pastikan perusahaan mematuhi semua persyaratan eksternal yang berlaku. Harapan yang ingin di capai pada proses ini adalah di level 4, predictable process. Berikut adalah sub-sub domain dari MEA03 Monitor, evaluate and assess compliance with external requirements:

Management Practice MEA03.01 Identify external compliance requirements. Deskripsi prosesnya adalah secara terus menerus, identifikasi dan monitor untuk perubahan dalam hukum lokal dan internasional, peraturan dan lainnya persyaratan eksternal yang harus dipenuhi perspektif TI. Kegiatan dari MEA03.01 Identify external compliance requirements, adalah: 1) Tetapkan tanggung jawab untuk mengidentifikasi dan memantau setiap perubahan persyaratan kontrak hukum, peraturan dan persyaratan eksternal lainnya yang relevan dengan penggunaan Sumber daya TI dan pengolahan informasi dalam bisnis dan operasi TI perusahaan; 2) Mengidentifikasi dan menilai semua persyaratan kepatuhan potensial dan dampaknya terhadap aktivitas TI di bidang-bidang seperti arus data, privasi, pengendalian internal, keuangan pelaporan, peraturan khusus industri, kekayaan intelektual, kesehatan dan keselamatan kerja; 3 ) Menilai dampak persyaratan hukum dan peraturan terkait TI mengenai kontrak pihak ketiga yang terkait dengan operasi TI, penyedia layanan dan bisnis mitra dagang; 4) Mendapat penasihat independen, jika sesuai, mengenai perubahan undang-undang, peraturan dan standar yang berlaku; 5) Pertahankan log terbaru dari semua persyaratan hukum, peraturan dan kontrak yang relevan, dampaknya dan tindakan yang diminta; dan 6) Memelihara daftar kepatuhan eksternal yang harmonis dan terpadu untuk perusahaan.

Hasil analisis dari Kegiatan dari MEA03.01 Identify external compliance requirements, adalah Institusi sudah melakukan seluruh proses diatas dan disimpulkan bahwa untuk proses MEA03.01 yaitu Identify external compliance requirements, di level 3 , established process, yang pencapaiannya berada pada sub level process definition attribute.

Management Practice MEA03.02 Optimise response to external requirements. Deskripsi prosesnya adalah meninjau dan menyesuaikan kebijakan, prinsip, standar, prosedur dan metodologi untuk memastikan bahwa hukum, persyaratan peraturan dan kontrak ditangani dan dikomunikasikan. Pertimbangkan standar industri, kode praktik yang baik, dan panduan praktik yang baik untuk adopsi dan adaptasi. Kegiatan dari MEA03.02 Optimise response to external requirements, adalah: 1) Secara teratur meninjau dan menyesuaikan kebijakan, prinsip, standar, prosedur dan metodologi untuk efektivitasnya dalam memastikan kepatuhan yang diperlukan dan menangani risiko perusahaan dengan menggunakan ahli internal dan eksternal, sesuai kebutuhan; dan 2) Berkomunikasi persyaratan baru dan berubah untuk semua personil yang relevan.

Hasil analisis dari Kegiatan dari MEA03.02 Optimise response to external requirements, adalah 
Institusi sudah melakukan seluruh proses diatas dan disimpulkan bahwa untuk proses MEA03.02 yaitu Optimise response to external requirements, di level 2, managed process, yang pencapaiannya berada pada sub level performance management attribute.

Management Practice MEA03.03 Confirm external compliance. Deskripsi prosesnya adalah Mengkonfirmasi kepatuhan terhadap kebijakan, prinsip, standar, prosedur dan metodologi dengan hukum, peraturan dan persyaratan kontrak. Kegiatan dari MEA03.03 Confirm external compliance, adalah: 1) Secara teratur mengevaluasi kebijakan, standar, prosedur dan metodologi organisasi dalam semua fungsi perusahaan untuk memastikan kepatuhan persyaratan hukum dan peraturan yang relevan terkait dengan pengolahan informasi; 2) Mengatasi kesenjangan kepatuhan dalam kebijakan, standar dan prosedur secara tepat waktu; 3) Secara berkala mengevaluasi proses dan aktivitas bisnis dan TI untuk memastikan kepatuhan terhadap persyaratan hukum, peraturan dan kontrak yang berlaku; dan 4) Tinjau ulang secara teratur pola kegagalan kepatuhan yang berulang. Bila perlu, perbaiki kebijakan, standar, prosedur, metodologi, dan proses dan aktivitas terkait.

Hasil analisis dari Kegiatan dari MEA03.03 Confirm external compliance, adalah Institusi sudah melakukan seluruh proses diatas dan disimpulkan bahwa untuk proses MEA03.03 yaitu Confirm external compliance, di level 2, managed process, yang pencapaiannya berada pada sub level performance management attribute.

Management Practice MEA03.04 Obtain assurance of external compliance. Deskripsi prosesnya adalah mendapatkan dan melaporkan kepastian kepatuhan dan kepatuhan terhadap kebijakan, prinsip, standar, prosedur dan metodologi. Konfirmasikan bahwa korektif tindakan untuk mengatasi kesenjangan kepatuhan ditutup pada a tepat waktu. Kegiatan dari MEA03.04 Obtain assurance of external compliance, adalah: 1) Dapatkan konfirmasi kepatuhan secara teratur terhadap kebijakan internal dari pemilik proses bisnis dan TI dan kepala unit; 2) Lakukan review internal dan eksternal secara reguler (dan jika perlu, independen) untuk menilai tingkat kepatuhan; 3) Jika diperlukan, dapatkan pernyataan dari penyedia layanan TI pihak ketiga mengenai tingkat kepatuhan mereka terhadap undang-undang dan peraturan yang berlaku; 4) Jika diperlukan, dapatkan pernyataan dari mitra bisnis mengenai tingkat kepatuhan mereka terhadap undang-undang dan peraturan yang berlaku terkait dengan perusahaan antar perusahaan transaksi elektronik; 5) Pantau dan laporkan masalah ketidakpatuhan dan, jika perlu, selidiki akar penyebabnya; dan 6) Mengintegrasikan pelaporan persyaratan hukum, peraturan dan kontrak pada tingkat enterprisewide, yang melibatkan semua unit bisnis.

Hasil analisis dari Kegiatan dari MEA03.04 Obtain assurance of external compliance, adalah Institusi sudah melakukan seluruh proses diatas dan disimpulkan bahwa untuk proses MEA03.04 yaitu Obtain assurance of external compliance, di level 2, managed process, yang pencapaiannya berada pada sub level performance management attribute. Tabel 4 Process Capability Domain MEA03 Monitor, evaluate and assess compliance with external requirements, memperlihatkan keseluruhan summary dari domain MEA03.

Tabel 4 Process Capability Domain MEA03 Monitor, evaluate and assess compliance with external requirements

\begin{tabular}{|c|c|c|c|}
\hline No. & Sub Domein & Current & Expected \\
\hline MEA03.01 & 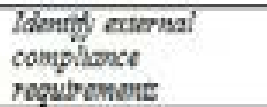 & 3 & 4 \\
\hline $\mathrm{MFA0302}$ & $\begin{array}{l}\text { Optimted rejponte it } \\
\text { enernal } \\
\text { requirements }\end{array}$ & 2 & 4 \\
\hline MEA 03.03 & $\begin{array}{l}\text { Camplom extemal } \\
\text { compliense }\end{array}$ & 2 & 4 \\
\hline MEA03.04 & 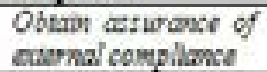 & 2 & 4 \\
\hline
\end{tabular}

Tabel 5 Index Level Process Capability Domain Monitor, Evaluate and Assess, memperlihatkan nilai index level kapabilitas hasil analisis yang dilakukan dengan menggunakan domain MEA01 sampai MEA03.

Tabel 5 Index Level Process Capability Domain Monitor,

Evaluate and Assess

\begin{tabular}{|c|c|c|c|}
\hline $\begin{array}{l}\text { Average } \\
\text { Domain }\end{array}$ & Domain & Current & Expected \\
\hline MEAO1 & $\begin{array}{l}\text { Monitor, ovaluato } \\
\text { and assoss } \\
\text { performance and } \\
\text { conformanea }\end{array}$ & 2.5458 & 4 \\
\hline $\mathrm{MEAO2}$ & $\begin{array}{l}\text { Monitor, roalwate } \\
\text { and assess the } \\
\text { system of intemal } \\
\text { control }\end{array}$ & 2.5869 & 4 \\
\hline MEA03 & $\begin{array}{l}\text { Monifor, evaluate } \\
\text { and assess } \\
\text { compliance with } \\
\text { external } \\
\text { roquirements }\end{array}$ & 2.5066 & 4 \\
\hline
\end{tabular}

Berdasarkan Hasil analisis yang sudah dirangkum diatas, maka domain yang memiliki hasil index level minimum adalah domain MEA03 (Monitor, evaluate and assess compliance with external requirements) sedangkan domain yang memiliki hasil index level maksimum adalah domain 
MEA02 (Monitor, evaluate and assess the system of internal control).

\section{SIMPULAN}

Beberapa kesimpulan yang dihasilkan dari penelitian ini adalahAudit Sistem Informasi Akademik (SIA) yang menggunakan Cobit 5 pada domain Monitor, Evaluate and Assess (MEA) di Universitas $\mathrm{XYZ}$ menghasilkan hasil yang menunjukkan bahwa SIA sudah dilakukan walaupun masih belum berjalan secara optimal karena belum mencapai pada tingkat kematangan yang diharapkan dan Sub domain yang memiliki hasil index level minimum adalah domain MEA03 (Monitor, evaluate and assess compliance with external requirements), dengan nilai 2.5066 sedangkan domain yang memiliki hasil index level maksimum adalah domain MEA02 (Monitor, evaluate and assess the system of internal control), dengan nilai 2.5869 .

\section{DAFTAR RUJUKAN}

[1] H. Agung \& J. F. Andry. Audit Sistem Informasi Akademik Menggunakan Kerangka Kerja COBIT 5 PADA DOMAIN EDM Di Universitas XYZ. Journal of Business and Audit Information Systems, Vol. 11, No.1, Hal. 38-49. 2018
[2] J. F. Andry. Performance measurement of information technology governance: A case study. Jurnal Sistem Informasi (Journal of Information System), Vol. 12, No.2, Hal. 56-62. 2016.

[3] A. K. Setiawan \& J. F. Andry. IT Governance Evaluation Using COBIT 5 Framework On The National Library. Jurnal Sistem Informasi (Journal of Information System), Vol. 15, No.1, Hal. 10-17. 2019

[4] ISACA. COBIT 5: Enabling Process. 2012, hal $13 .$.

[5] ISACA. COBIT 5: a Business Framework for the Governance and Management of Enterprise IT. 2012, hal 24.

[6] ISACA. Process Assessment Model (PAM): Using COBIT 5," USA:ISACA. 2012, hal 53.

[7] A. Pasquini \& E. Galie. COBIT 5 and the Process Capability Model. Improvements Provided for IT Governance Process. Proceedings of FIKUSZ '13 Symposium for Young Researchers, Published by Óbuda University, Hal. 67-76, 2013.

[8] R. Wijaya \& J. F. Andry. Performance measurement of $J P$ soft application using COBIT 5 framework. Jurnal Ilmiah Teknologi Sistem Informasi, Vol. 3, No.2, Hal. 83-93. 2018.

[9] J. F. Andry and K. Christianto. Audit menggunakan COBIT 4.1 dan COBIT 5 dengan Case Study. Teknosain. 2018, hal 122. 